7 Maier GW, Newton JR, Wolfe JA, et al. The influence of manual chest compression rate on hemodynamic support during cardiac arrest: high-impulse cardiopulmonary resuscitation. Circulation 1986;74(suppl IV);51-9.

8 Evans TR, ed. $A B C$ of resuscitation. London: BMJ Publications, 1986.

9 Jaffe AS. Cardiovascular pharmacology I. Circulation 1986;74(suppl IV):70-4.

Guerci AD, Chandra N, Johnson E, et al. Failure of socium bicarbonate to improve resuscitation from ventricular fibrillation in dogs. Circulation 1986;74(suppl IV):75-9.

1 Otto CW. Cardiovascular pharmacology II: the use of catecholamines, pressor agents, digitalis and corticosteroids in CPR and emergency cardiac care. Circulation 1986;74(suppl IV):80-5.

Paraskos JA. Cardiovascular pharmacology III: atropine, calcium, calcium blockers and $\beta$ blockers. Circulation 1986;74(suppl IV):86-9.

3 Thompson BM, Steuven HS, Tonsfeldt DJ, et al. Calcium: limited indications, some danger. Circulation 1986;74(suppl IV):90-3.

4 Bedell SE, Delbanco TL Cook E, Epstein FH. Survival after cardiopulmonary resuscitation in the hospital. N Engl f Med 1983;809:569-75.

\title{
Stepping carefully through trade union legislation
}

\section{$B M A$ must be careful of infringement}

Could the BMA fall foul of trade union law through its campaign against the NHS white paper? The association is a trade union subject to the Trade Union Act 1913, which says that union funds must not be used to further political objects unless the objects have been approved by a ballot of members and payments are made out of a separate political fund. The leadership of the association is aware of this problem and has circulated advice.

Despite often criticising the government of the day the BMA has always maintained a neutral political stance. Unlike many of the large unions the association has never adopted political objects and maintains no political fund. Therefore it may not spend money on any of the activities spelt out in the act, as amended by the Trade Union Act 1984. The changes made by the Conservative government in 1984 cover almost every conceivable type of political activity-from providing financial support for members of parliament to paying for a brass band at a political rally.

The restriction that could trip up the BMA is the section that lays down that a union must not spend money, except from a political fund, "on the production, publication or distribution of any literature, document, film, sound recording or advertisement the main purpose of which is to persuade people to vote for a political party or candidate or to persuade them not to vote for a political party or candidate."

This would apply not only to staff but also to committees, subcommittees, divisions, regional craft committees, and local medical committees. The restriction does not apply to members of a union acting in their personal capacity.

The act tripped up the National and Local Government Officers' Association (NALGO) in 1987. The union, which had no political fund, was taken to court by two of its Conservative members who were trying to stop a $£ 1 \mathrm{~m}$ campaign arguing for more money to be spent on public services and timed to coincide with local elections and the run up to the general election. Leaflets targeted on marginal seats suggested that the Tory government was responsible for waiting lists, unemployment, and the state of the NHS. The High Court granted the injunction, declaring the campaign-which included specific references to voting in leaflets and posters: "You have a voice. You have a vote. Make people matter"; "Questions to ask before you vote"; and "Think before you vote"- unlawful despite a disclaimer that the union was not seeking or opposing the election of any group of candidates.

\section{BMA advice on campaigning}

BMA committees and subcommittees (including divisions, regional craft committees, and local medical committees) should not:

- Produce, publish, or distribute any document that attempts to persuade people to vote for a particular party or candidate or to dissuade them from voting for a particular party or candidate

- Publish material that gives voters grounds to assume that the BMA encourages them not to vote for a particular party or candidate

- In the run up to an election-including general elections, by elections, council elections, or European electionssupport a candidate in any way, including by canvassing, giving funds, or providing administrative help such as telephoning, fax facilities, printing, or photocopying

- Make any comment on any aspect of the BMA's campaign which could be associated with an election without first seeking guidance from the public affairs division.

Doctors using their own leaflets and posters as part of the NHS campaign must ensure that the BMA's name is not associated with any printed material-including videos, slides, and newspaper advertisements - if it could be interpreted as trying to influence the public on how to vote. Doctors must also remember the proscription on spending money on producing personal leaflets and posters.

In giving judgment ${ }^{1}$ the Vice Chancellor, Sir Nicolas Browne-Wilkinson, noted the timing of the campaign and emphasised that nothing in his judgment should be taken as suggesting that a publicity campaign organised by a union at times other than an election - and therefore at a time when the union could not directly or indirectly be inviting people to vote-would be unlawful merely because it expressed disapproval of the government's policy.

Sir Nicolas refused to rule on whether the campaign also breached section 75 of the Representation of the People Act 1983, another possible danger zone for BMA divisions and committees. This makes it a criminal offence before elections -including by elections, council elections, and European elections - for any person without the approval of a candidate's election agent to incur expenses with a view to promoting or procuring the candidate's election by holding public meetings or displays, issuing advertisements or circulars, or presenting views that might disparage other candidates.

The BMA, its committees, and its representatives need to be careful not to step over the boundary drawn by the Trade Union Act 1983 and use union funds in an attempt to influence votes. It need not, however, be troubled by visions of sequestration of its funds, as happened to the miners', print workers', and seamen's unions when they found themselves on the wrong side of the law in industrial disputes. Only a dissident member could take the association to court; the government has no right to do so. And the remedy is an injunction to stop the unlawful political activity. Only if the BMA defied such an injunction would it risk having its assets sequestrated.

Legal correspondent, $B M \mathcal{F}$

CLARE DYER

1 Paul and Fraser v NALGO. Industrial Relations L.aw Reports 1987:413. 